\title{
Facebook as a Local and Community Digital Media? Experiences Impacting on the Unemployed Audiences of the Project "REviver na Rede"
}

\author{
João Pinto ${ }^{1 *}$ \\ (D) 0000-0002-8161-2513 \\ Teresa Cardoso ${ }^{2 * *}$ \\ (iD) 0000-0002-7918-2358 \\ ${ }^{1}$ LE@D - Laboratório de Educação a Distância e Elearning, Universidade Aberta, PORTUGAL \\ 2 Universidade Aberta, Departamento de Educação e Ensino a Distância (DEED); LE@D, Universidade Aberta, PORTUGAL \\ *Corresponding author: joao.pinto@uab.pt \\ ${ }^{* *}$ Corresponding author: teresa.cardoso@uab.pt
}

Citation: Pinto, J., \& Cardoso, T. (2021). Facebook as a Local and Community Digital Media? Experiences Impacting on the Unemployed Audiences of the Project "REviver na Rede". Online Journal of Communication and Media Technologies, 11(3), e202109. https://doi.org/10.30935/ojcmt/11080

\section{ARTICLE INFO}

Received: 27 Sep 2020

Accepted: 7 Jun 2021

\begin{abstract}
In the context of globalization, the Project "REviver na Rede" emerged as a response to a specific problem (unemployment) felt within a regional community (audience). Our threefold theoretical framework covers the perspectives drawn from a literature review on: networked society; social networks; unemployment and sociability. These theories sustain the practices put forward, taking advantage of the digital tools and features provided by Facebook. The impact of involving local audiences helped us achieve a valuable engagement, for instance through a prompt and assertive interaction, or a pedagogical moderation. Content curation and motivational communication also proved to be successful strategies to meet those aims. In short, the implementation of the project highlighted the fact that Facebook can contribute to manage employability factors, like the isolation and social exclusion in unemployment. We conclude, therefore, that this digital online social network is a valid tool for the integration, socialization and active job search, helping to improve employability. Ultimately, Facebook can act as a local and community digital media, facilitating experiences impacting on its audiences, among which the unemployed members of the online "REviver na Rede" page and group.
\end{abstract}

Keywords: networked society, social networks, Facebook, unemployment, digital literacies, Project "REviver na Rede"

\section{INTRODUCTION}

We live in a globalized society, structured according to networks mediated by technology, in which phenomena such as cyberculture and participatory culture emerge, enhancing the individual's ability to fulfill themselves as a social being and "completely changing the possibilities of communication." (Vermelho et al., 2014, p. 186). Thus, it is essential to guarantee the democratization of access to the latest means of searching, storing, managing and sharing information, so a more equitable society can be built.

Digital social networks empower people, but can pose a danger to those who don't know how to use it. Thus, digital literacy emerges as a key concept of our networked society, where each citizen is required to have skills to "communicate in a more effective way, but also to face in a critical way" (Furtado, 2007, p. 109) the social changes of the world around it. There is now a greater focus on the skills of analysis and critical reflection of information, on the production and sharing of knowledge, but also on "the ability to use these social skills, together with others, in an effective way." (Rheingold, 2012, p. 5). 
The most recent technologies place in our hands a set of educational resources that allow to boost and increase the practices of Open Education and methodologies centered on the learner. In addition, Open Educational Resources (OER) make it possible for "the main actors in the educational process [to be] [...] away from structured curricula followed by formal educational institutions" (Santarosa et al., 2014, p. 16). They also make powerful resources available for sharing, collective constructing and socializing of knowledge accessible to everyone, which makes informal learning possible as an engine of lifelong learning.

While these transformations were taking place, Facebook emerged from a set of digital social networks, acquiring ubiquity and worldwide influence, as a "gigantic collaboration network" (Kirkpatrick, 2011, p. 340), encouraging people to use the internet with more social interactivity. According to him, Facebook is changing the way hundreds of millions of people interrelate and share information, empowering the individual, enabling them to communicate more effectively.

This framework has supported the genesis of the Project "REviver na Rede", which we present, as a practical case of using the internet for the personal development of individuals and their communities, taking into account communication, interaction and sociability in social media networks, as a means to promote new forms of inclusion and active job search.

In the following sections, we further explore our theoretical framework, organized in a threefold perspective: networked society; social networks; unemployment and sociability.

\section{THE PARADIGM OF A NETWORKED SOCIETY}

The technological revolution brought about a new social paradigm, described by Castells (2011) as a "networked society", based on the power of information. We inhabit in a time when information circulates intensely, constantly being updated, and in which knowledge is a resource always under reconstruction and expansion.

Ours is a globalized society, structured in networks mediated by technology, without geographical nor temporal boundaries. We live in a new era, offering us multiple possibilities to learn, regardless of space and time, through new structures, conveying new means for individual and collective development throughout life.

The human being can be understood as a construction of the social networks that surround him. Throughout his evolution, man realized that social interaction empowered him with survival and dominance in the surrounding world. Thus, society is made up of individuals and institutions, operating in several spheres, both at a local and global level, in the search and enhancement of improving the quality of life in its social, cultural, political and economic dimensions.

We witness, therefore, an enrichment of our interactions, the result of the integration of new technologies by society. In fact, the evolution of technology has implied new productive capacities, new standards of living, as well as new forms of social organization. That is,

the emergence of the networked society is the result of the interaction of two relatively autonomous forces: the development of new technologies and the society's attempt to reconcile itself with the use of the power of technology to serve the technology of power. (Castells, 2011, p. 69).

Hence, our (individual and collective) existence is shaped and mediated by technology in a network logic. The "network is a set of interconnected nodes" (Castells, 2011, p. 606) that allows to process, strengthen and disseminate the knowledge previously built, based on the shared information. This new knowledge can, in turn, bring new meanings to the knowledge of individuals who will be connected to that network.

However, for Braudel (1967), "technology does not determine society: it incorporates it. But society also does not determine technological innovation: it uses it" (p. 6). This dialectic interaction between society and technology defines a new social reality, crosses borders and reaches people with different social and cultural backgrounds, resulting from a global evolution of society itself.

Therefore, it is possible to consider that technology can have an impact on the individual's lifestyle and behavior in society, as well as on their habits and routines. Nowadays, we meet with our friends through web- 
based media social networks; a few years ago, we met them exclusively in physical spaces (e.g., in cafes). The cyberspace increasingly assumes itself as a space for socializing in our society and the use of new technologies has, necessarily, an effect on the social dimension of our lives. Because "technology is neither good nor bad and neither is it neutral" (Castells, 2011, p. 94). That is, technology is not a closed system, but it evolves into an adaptive, comprehensive and open network that transforms our relationship with the world.

In short, virtualization is a consequence of our experience as members of a globalized, networked society, centered on the use of information and knowledge, implying a continuous process of transformations, namely of the physical relationships. This allows us to "be whatever we want. We can completely redefine ourselves if we wish." (Turkle, 1997, p. 26). This virtualizing our social lives is compatible with the daily life of an unemployed person, who is also subject to a new reshaping of space and time, where life processes are reconstructed, and while new forms of communication are recreated, physical barriers are broken, thus enhancing new opportunities for interaction, including in social (digital) networks, which we will consider next.

\section{THE PARADIGM OF SOCIAL NETWORKS}

To better understand the importance of living in a network, we consider the principle that "the whole is more than the sum of the parts." (Gispert, 1999, p. 95). It is an inspiration in the Gestalt ${ }^{1}$ theory, according to which a set of human beings have properties that do not exist individually, thus allowing them to produce things that previously would not have been possible. "The problem of the small world" by Milgram (1967) demonstrated that the expression "the world is small" is not just a cliché, and that each human being is linked to any other human being by a surprising small number of people. This seems to confirm the impression "that it is often the case that when someone meets a new person, they conclude that there is a third person that they both know." (Lopes and Cunha, 2011, p. 17).

We have integrated a world dominated by networks and we are starting to understand how they affect us. Our social life and behavior can be influenced by people we don't know, but who are friends of our friends' friends on the digital social networks, just as we are influenced by people we know directly. In this scenario, Recuero (2009) defines social network as "a set of two elements: actors (people, institutions or groups; the nodes of the network) and their connections (interactions or social ties)" (p. 24). In the words of Hoffman and Casnocha (2014), "it is a set of people and the connections that unite them" (p. 10).

The advent of the internet has brought numerous changes to society; one of the most significant is the possibility of expression and socialization through computer-mediated communication tools. These new web tools have brought the possibility for people to be able to (re)build, interact and communicate with others, leaving tracks that allow the recognition of the patterns of their interactions and the visualization of their presence on digital media and social networks. In fact, "the human being is, above all, a social being" (Vermelho et al., 2014, p. 186), and the digital environment, according to these authors, allows "to extend and expand the reach of traditional social networks to make new forms of sociability possible" (Rheingold, 2012, p. 192).

Digital technologies play a central role in the profound changes in our social life "and the speed of the process has been staggering." (Recuero, 2009, p. 12). So, "what makes current social networks different is precisely the fact that they are supported by a digital technological infrastructure that [...] allows to overcome the constraints of time and space." (Dias, 2014, p. 56). From the moment that technology started to mediate social relations and the ordinary citizen became digital, the connections were shortened, becoming, each one, a node in a digital network. Some individuals are nodes with few connections and others are "super" nodes, with countless connections, which gives them greater social value. For Lopes and Cunha (2011), each person has their "social value" in the networks in which they participate, which influences the other people with whom they relate to. Thus, the presence that each has on the network is a powerful instrument for success, both personally and professionally.

In short, people who are present in a network in which they participate - whether commenting on a publication, sharing content, participating in a virtual community or contributing in other ways to online

\footnotetext{
1 Gestalt in German means "form". In psychology, the term is used to express the whole, within the theory proposed by Max Wertheimer (1880-1943) to study how human beings perceive things.
} 
(participatory) culture -, see themselves as active citizens, (co)builders of collective intelligence (Latour, 2012; Lévy, 2003). However, and as mentioned, the digital social networks only empower people who learn how to use them, unveiling a weakness for those who do not know how to use them. For example, it is extremely easy to find fake information and profiles, view offensive content, or pay attention to redundant content. These situations represent increased risks for untrained and more unaware users of the potential dangers of social networks, for people who do not have the core literacies. On the internet, as in non-digital situations, it's essential to learn about the places we should go to, how to behave and what to do; in circumstances of unemployment, as discussed below, such sociability standards are also valid.

\section{THE PARADIGM OF UNEMPLOYMENT AND SOCIABILITY}

Unemployment is a current reality, and has become a transversal phenomenon in many countries and economies. Many authors describe it as "often a cause of poverty and rupture of social ties, stigmatizes the individual and calls into question his social status." (Loison, 2000, p. 1). These situations of unemployment, especially those of long term, can "cause serious problems both in terms of the subsistence of the individuals and in terms of their status and social ties" (Bento, 2011, p.14), leading to situations of social exclusion and isolation.

Work in our society assumes a central role in the individual's experiences, because it is seen as "the mediated satisfaction of desire and want. It is a process of transformation of the individual" (Oliveira, 2005, p. 967), making him an active member of society. Thus, the fact of having a job corresponds to having a place in the society, and it "is one of the factors that lead to social insertion and recognition" (Arcoverde, 1998, p. 4). Not having a job generally means "being without support, without protection and living in a state of dependence that tends to perpetuate itself, especially in populations already in need and with low qualifications" (Santos, 2010, p. 31). Although the situation of unemployment is a transition phase, rather limited in time, it incorporates some degree of change and uncertainty requiring individuals to adapt, which is not always easy.

The incorporation in the labor market allows the individual to have, in addition to a salary and access to certain social rights, the outline of a personal identity and a high self-esteem. This relational dimension leads us to the networks of relationships that foster integration and sociability, for instance, with family, friends, neighbors or colleagues at work. When these networks fail, the individual enters a process of nonidentification, which can lead to social self-exclusion, because a "loss of relational ties (...) marks the individual's rupture with the social environment that surrounds him." (Santos, 2010, p. 11). Unemployed individuals end up "becoming more fragile and vulnerable to situations of social exclusion" (Marques, 2009, p. 112), indeed many of them are left on the margins of society.

It is important to mention that when considering social exclusion, we take into account "all spheres [networks] that society includes, whether it is the family, the network of friends, the local or cultural community, the political or economic systems" (Santos, 2010, p. 10). Thus, the greater the number of social spheres (networks) from which the individual moves away, the deeper his state of social exclusion will be, which tends to increase as the time of his unemployment condition increases, in a snowball effect.

With regard to sociability in unemployment, we consider that the meaning of sociability is related to the nature of the human being living in society. As a social being, he always has the desire to be integrated with other human beings, his fellow peers. Thus, sociability can be defined as the "human capacity to establish networks, through which the units of activities, individual or collective, circulate tastes, passions, opinions, etc." (Baechler, 1996, as cited in Arcoverde, 1998, p. 1). We can perceive it exists to connect human beings, through the daily interactions in their lives.

In this context, we also consider the employability of the individual. Although it has only recently become widely used, the concept of employability is not new. According to Alberto (2005), its origin dates back to the beginning of the $20^{\text {th }}$ century in Great Britain; later it was adopted in the United States, and later still in other countries in Europe. However, over time, the concept has undergone mutations, which have been determined by economic and social transformations. 
Even though the concept of employability is yet lacking in a single unique consensus, its definitions "all refer to the ability of individuals to experience transitions in the labor market in which they are inserted, which results from skills, knowledge and adaptability" (De Cuyper et al., 2008 as cited in Boto, 2011, p. 66). In other words, they refer to the ability to get a job or to adapt professionally to a job. To this definition, Cardoso et al. $(2012$, p. 8) add that employability also designates "the quality or possibility of having a job (...) for others or self-employment". In turn, Alberto (2005) associates employability with structural unemployment scenarios, which justifies the impossibility of professional insertion of individuals; the author argues that "the development of employability would be the passport for entering the job market." (p. 162). As for Boto (2011, p. 6), employability "absorbs a series of constructs centered on the individual (e.g. career identity, personal adaptability, proactivity) that combine synergistically in order to help" individuals to adapt to new realities. Hence, he sustains that employability is a "psychosocial construct with an emphasis centered on the individual, which incorporates individual characteristics that favor a cognitive, behavioral and affective adaptation" (idem). As such, employability refers to much more than knowledge, skills and competences; it includes characteristics of a higher order that allow individuals to adapt to the demands of the environment, responding proactively to opportunities.

Being employed is important for subsistence (it is a source of income), and is also "a guarantor of social status or a promoter of socialization networks" (Bento, 2010, p. 3), where "the friendships formed in the environment are an important factor in the satisfaction of individuals" (Macedo, 1996, as cited in Arcoverde, 1998, p. 4). In contrast, unemployment "symbolizes a rupture in socio-professional trajectories, with different impacts on the personal and collective life of individuals", and it entails a departure from social life, on the border of social rupture (Marques, 2009, p. 113).

It is through everyday experience in the work environment that it becomes possible to create bonds of friendship and social relationships that are important for the lives of the individuals. When facing unemployment, one of the main means of maintaining sociability networks is lost. Relationships become more difficult over time, as there is no close and daily coexistence with former colleagues. Thus, unemployed people can experience isolation and certain processes of social exclusion.

In fact, interpersonal relationships and the network of contacts are vital "for the relationship with people and companies, as it makes it possible to prospect for new business or new job opportunities" (Oliveira, 2005, p.701), which is why they are fundamental for the reintegration / adaptation of individuals to new social settings. Thus, it is important for our professional life to be aware of the dynamics that can be created in new social networks and the source of opportunities that they can entail; job search is one of them. Lopes and Cunha (2011) argue that the way we "integrate into these networks can determine the greater or lesser probability of getting a job" (p. 8).

It is possible to consider that many people find employment through a friend or someone they know. This idea, often associated with common sense, is related to the importance of the networks we have established in our (non-digital) life. It is often not enough to just have the best professional skills to get a job; we also need to have some social skills, that is, connections that put us in touch with job opportunities. Thus, it is vital to know people who have the right information about a certain recruitment process, and, most of all, who have some kind of decision-making power. A social network allows us to manage these contacts with close friends and people who are only slightly known to us, which evokes and reminds us of the strength of the (strong and weak) bonds.

According to the studies by Mark Granovetter, discussed by Lopes and Cunha (2011), the people who are only slightly known to us (our weak ties) play a crucial role in the search for a job, even more than the closest friends (our strong ties). The mobilization of these relationships becomes a key factor for the active job search, as an activity that can be facilitated through digital media and social networks.

Nowadays, it is very common for a person to belong to a digital social network, and thus being connected to countless other people and institutions. In that virtual space, an individual shares states, tastes, interests and achievements, personal and professional, which shows that we live in a global society, where space and time are relative. Faced with this new paradigm, the job market has also reached a global dimension; the data, which define our identity, are accessible anywhere, anytime. The internet has become a place for people to look for work and companies to hire. In this context, digital social networks, due to their characteristics of 
interaction and dissemination of information, have become a perfect medium for such dynamics. Thus, companies are able to recruit the best, faster, and at a much lower cost, avoiding, for instance, subcontracting consulting companies to mediate in those processes. Companies have direct access to potential candidates, and, increasingly, to a set of information from their employees' digital profiles.

Technologies are evolving very quickly, with a significant impact on our daily lives, but also on the labor market, as can be perceived by the theoretical evidence we have been referring to. So, it is essential to provide citizens with digital skills that allow them to adapt to the jobs of the future. The qualification of individuals in technological areas appears as a great driver for the necessary changes, from basic to university education. This also implies that the individual is able to carry out digital actions in the field of work, education, leisure and other aspects of daily life (Martin, 2005), which triggers the need to access to lifelong learning processes.

Thus, digital skills are "intrinsically related to employability, as the digitalization of the labor market requires new skills" (Pinto, Cardoso, \& Pestana, 2019, p. 28). A society composed of individuals trained to live in the digital world "generates more new jobs, as well as markets and innovative products, generating more competitive and robust economic activities" (FCT, 2017, p. 2). Learning, productivity and competitiveness are also variables that are increasingly dependent on digital, forcing an increasing demand for digital skills in the exercise of different professions.

The United Nations, through the $2030 \mathrm{Agenda}^{2}$, recognizes the importance of new digital competences, as well as the access to inclusive education and lifelong learning, to improve employability, encouraging governments to mobilize efforts, through the application of the Sustainable Development Goals, to make the future society more just and balanced. The European Commission estimates that, by 2020 , more than $90 \%$ of jobs in Europe will require diverse digital skills, thus reflecting the decisive role that technology and its effective applicability have today in professional life.

With regard to Portugal, it is one of the countries with the greatest deficit in digital skills, as a large percentage of its population does not follow the inevitable digital evolution. In the report of the National Strategy for Digital Inclusion and Literacy (FCT, 2015), it is concluded that more than half of the Portuguese population does not have the necessary skills to take advantage of digital tools, a fact with a huge impact on employability.

Nevertheless, in recent years, "there have been several initiatives to address these concerns, both at the institutional level and at the level of civil society" (Pinto, Cardoso, \& Pestana, 2019, p. 29). Among the most recent, it is worth mentioning the INCoDe.2030 program ${ }^{3}$, a government initiative aligned with the 2030 Agenda and the Europe 2020 strategy $^{4}$, in order to reinforce the basic skills in Information and Communication Technologies (ICT) of the Portuguese population, preparing it for emerging and digital-based job opportunities.

For Afonso Carvalho, responsible for a study carried out in Portugal by the company Kelly Services, "it is evident that social networks are changing the way people look for work" (Kelly Global Workforce Index, 2011, p. 2). They are learning that there are positive and negative aspects, and they need to take advantage of the best of what the internet can offer to them at a professional level. For example, the study points out that " $16 \%$ of the respondents say they fear that the content they make available on social networks may negatively affect their careers". It also shows that " $18 \%$ of the respondents say it is essential to remain active on social networks". These numbers confirm the existence of an awareness of the importance of the social networks for employability, namely the quality of the presence of each person in these online spaces.

As for Facebook, the study concludes that it is the "most popular social network to find work" (Kelly Global Workforce Index, 2011) across all generations, which might be related to its great popularity, as it is transversal to all groups using it, as to the companies that need to hire. In fact, today, it is already common for companies to publish their recruitment ads on Facebook, thus shared and reaching a higher audience than that of traditional media. On the other hand, the aforementioned study also shows that Facebook users are

\footnotetext{
2 https://sustainabledevelopment.un.org

${ }^{3}$ http://www.incode2030.gov.pt

${ }^{4}$ https://infoeuropa.eurocid.pt/registo/000044430/documento/0001
} 
increasingly aware of the possibility of finding job offers on this online social digital network, perceiving it as an important means for an active job search.

In short, for unemployed people, it is essential to continue to create and manage their sociability networks, as indicated by Duarte (1998), noting that there are many cases of professional reintegration due, above all, to "the mobilization of personal and relational resources" (p. 302). The resources available on the internet, such as in Facebook, offer new opportunities for sociability in situations of unemployment. Because they reduce the physical distance that separates people from their old networks, they allow to manage and entail new social interactions, and even make it possible to create new networks of sociability. This was a foundational assumption in the context of the Project "REviver na Rede", as it is described in the following section.

\section{CONTRIBUTIONS OF THE PROJECT "REviver na Rede" TO THE NETWORKS AND SOCIABILITY OF UNEMPLOYED AUDIENCES}

Our research has been inspiring the practices of the project "REviver na Rede", based on which we sustain that social (digital) networks, namely Facebook, are valid tools to promote informal learning throughout life, but also "for [the] integration, socialization and active job search, helping to improve employability" (Pinto, 2017, p. 86). We are increasingly witnessing a large number of individuals with a professionally active life history, who face unemployment for the first time, a situation for which they are not psychologically prepared.

The project was born in an academic context, within the scope of a master dissertation in E-Learning Pedagogy (Pinto, 2017), to meet the problem of "isolation and social exclusion in unemployment as factors that are detrimental to employability" (Pinto, 2017, p. 30); it has been implemented since 2015 in the Autonomous Region of Madeira, strongly dependent on tourism. With the global economic and financial crisis of 2007-2008, the region recorded high rates of long-term unemployment, a situation that lasted for many years, with serious consequences for the social integration of individuals, now extended with the COVID-19 pandemic.

The project's main goal is to support unemployed people in using Facebook to socialize, avoiding social isolation and self-exclusion, in addition to promoting new forms of active job search. To this end, we have been seeking to develop new literacies and digital skills, integrating the tools available, such as those promoted by and using Facebook, in the social daily life of this type of population. The project has a strong pedagogical, social and solidarity scope, provided by voluntary work by regional communities, in a social entrepreneurship spirit; it aims to be a model of social integration and personal development, possible to be replicated in other communities.

Initially, the target audience of the project was unemployed people living in Madeira, but we noticed a strong interest of other people, namely employees looking for new job opportunities and family/friends of unemployed people. Less expected was the involvement of emigrants, mainly from countries like Venezuela, South Africa and England. It should be noted that emigration has always had a great expression in Madeira, being accentuated by the crisis earlier mentioned. We noticed that some of the emigrants used the online spaces of the project to discover the openness of the labor market in the region, considering the possibility of returning back to Madeira, which indicates that the project is also a contribution to the reintegration of emigrants, encouraging the improvement of their skills, mainly in the use of Facebook, to get a job (at a distance) in their communities of origin.

In the contemporary society, "the access and maintenance in the labor market are closely linked to the lifelong learning process" (Paixão, 2021, p. 58), which results in a need for initiatives that involve individuals, communities, educational institutions and social stakeholders. Therefore, the Project "REviver na Rede" can contribute with guidance, "in order to help individuals make choices and manage their careers" (OECD, 2005), in addition to contributing to establish connections with their communities. Paixão (2021) also recalls that such guidelines are a key-area of European policies, and should be early, continuously, accessible; they should combine different methods and approaches, and involve the use of ICTs, as they expand their reach, without limitations of territory or physical space. This is how we perceive the Project "REviver na Rede", as an instrument to support individuals choosing the digital social networks as a space of intervention. 
Diagnostic studies, carried out in the preparatory stage of the project, indicated that digital social networks had the potential to integrate a solution, specifically Facebook. This social media tool, connected to globalization, can respond to the demands of local communities and contribute to their development. In fact, Facebook proved to be the best platform to promote communication and sharing between individuals with different characteristics, namely different ages, while having in common, as collectives, similar goals and needs. Recently, the project has been advancing with pilot tests on other digital social media networks, such as Instagram, Linkedln and Twitter.

With regard to content production, three online spaces were developed, for different purposes: a website (acting as the institutional space of the project, and catering for learning content); a Facebook page (acting as a marketing hub of the project, and a broadcaster of learning content); a Facebook group (providing for interaction between members and content dissemination).

In digital social networks, content is of the utmost importance. For Coutinho (2014),

it is a determining factor for someone to like or dislike the page (...); it is a key element in creating a close relationship with your community (...); it will generate greater interaction on the part of the followers (...) and help to fulfill the objectives [of the project] (p. 127).

Aware of these advantages, we created several types of content to upload on the project's Facebook page and group. Some contents contain a catalyzing message for learning, others assume a more motivational objective and the construction of an environment favorable to learning. We then summarize the contents and tools that have been revealed to work best.

As the project website is the place where most of the learning content is located, we take advantage of its online existence to share it on Facebook and thus achieve greater visibility with the target audience. In addition to promoting learning outside the website, in a more informal and accessible place, Facebook is also a way to publicize the project itself.

We also use the Facebook event tools to promote learning moments through which we invite the project's audiences to perform a specific task. It allows us to have "a space reserved for a specific event, which will take place on a specific day and date, but which does not always correspond to a physical event." (Coutinho, 2014, p. 74). Thus, for some, these moments meant becoming aware of the knowledge they already had and alerting them to what they still needed to acquire. For others, it represented the challenge of carrying out the task, an impetus for learning, namely about the procedures necessary to perform it. Therefore, we use events as an invitation to learn, creating greater dynamics and involvement in the project.

The sharing of news and articles published on other sites, usually online newspapers and magazines, has assumed a strategic importance to strengthen information literacy. When we find content, somehow related to Facebook and digital social networks, we share it on our Facebook page. Whenever possible, we add a reflective and guiding text on the subject addressed to help further contextualize it. These publications take on a content curation feature as a way of "distributing the information we collect, after we have perfected and contextualized the implicit knowledge, to improve its credibility and meet the needs" (Rheingold, 2012, p.249) of the target audience. We emphasize that the concept of content curation is characterized by the process of researching, organizing, collecting and sharing the best contents (texts, photos, videos, tools, posts, etc.), under a given theme. Thus, we had the intention to help in the interpretation of the curated contents, to add value and to make them more appealing, taking into account the context in which they are shared. In other words, we believe in content curation as a process that "catalyzes and facilitates the learning of other individuals" (Tavares, 2013, p. 13).

Direct and individual interaction with the followers of the project has been a core aspect from the start, becoming, over time, an asset for achieving the goals of the project. Facebook allows followers of a page to contact the administrators through a direct message. We use this functionality to establish a personalized dialogue with those who contact us, to clarify their doubts and provide them with some guidance. At the end of each message, we take the opportunity to introduce them to the project and to show how to use it. In specific situations, we use this private communication space to propose some actions to overcome some aspects detected in the misuse of digital social networks, which can only be done in a personal dialogue. 
Another of the Facebook features used on a regular basis is the survey tool, which allows to ask group members about a particular subject. It makes it possible to ask a certain question, with a closed answer; it is accessible to all members, and it enables to count the answers given. We used this tool to boost the group's activity around the themes of the project, to get to know the members better, in addition to perceiving their opinion on certain issues, in order to build other content and/or redefine strategies for interaction.

The type of publication that creates the most involvement with the project are job advertisements, as the search for job advertisements is what moves the target audience of the project. Hence, we share, on the project's Facebook spaces, job advertisements that we find in the most diverse media (printed or digital). We understand that sharing ads helps to seize the attention of our audiences, to increase the visibility of the learning contents and, so, to achieve the project's purposes.

We emphasize that the contents and tools mentioned above are representative, with regard to their use, the results achieved and the easiness of use in the Facebook environment. Although many others have been adopted, throughout our experience within the project, we have found out that the interaction with followers is the strategy that achieves the best results. Thus, we highlight the importance of responses to comments on publications and private messages, in which we encourage moderation with a prompt, assertive and pedagogical reaction.

Analyzing the involvement of people with the "REviver na Rede" online spaces, in 2018, the year of evaluation of the project, the Facebook page had 21,431 followers, the Facebook group 27,697 members and the website registered 44,495 clicks, of which 16,467 were returning visitors. To better understand the scale of the number of members of the group, we mention that there were approximately $12,200^{5}$ unemployed people in Madeira (so we can say that the universe of the target population was smaller than the members of the group), and that the population of the region accounted for $254,876^{6}$ people. Therefore, taking the group's total members $(27,697)$ for comparison, we note that they represented about $11 \%$ of that population.

Characterizing the type of followers of the project, the studies carried out through questionnaires indicated an average age of 31 years, 55\% women, low levels of education (the $4^{\text {th }}, 6^{\text {th }}$ and $9^{\text {th }}$ grades stand out), and $54.5 \%$ unemployed. It should also be noted that $11 \%$ of the respondents who mentioned they were employed stated that they had Human Resources selection/recruitment responsibilities, suggesting that the project online digital spaces are also followed by professionals in the recruitment area, as confirmed by the many requests sent to us (e.g., to run ads with job opportunities).

The evaluation carried out two years after the beginning of the implementation of the project revealed that it had reached the intended goals and aims, as a solution to the problem identified within the target audience, through evidence of changes in behaviors in the use of Facebook by the project audiences/followers. The online digital spaces managed on Facebook have become very dynamic, registering testimonies from people who got jobs (in a total of 529 people by 2018) through the job offers shared by us. But we also received testimonies from people who said that they are more aware of the potential of Facebook and that they are using it better, even on a personal level.

The main objectives that guide the project are related to changing behaviors when using Facebook, which we know is difficult to observe, monitor and document. However, as described, the assessment studies point to some evidence. At the beginning, we observed that in the interactions recorded on the Facebook page and group there were members with very unreasonable and inconvenient participation, especially in their comments. In addition to disturbing other interactions, they were negative for the image of those who did them, which could be very damaging for potential applications for job offers. But, over time, we started to see that they were decreasing, becoming rare when evaluating the project. This evolution can result from our moderation, and to the learning of some of the contents made available by the project, as many of our followers stated they gained awareness of the importance of the interactions and publications carried out in the construction of their profile on digital social networks, and, consequently, in their success in an active job search.

\footnotetext{
${ }^{5}$ Estimate of the unemployed population in the $3^{\text {rd }}$ Quarter of 2018 (source: Regional Directorate of Statistics of Madeira, https://estatistica.madeira.gov.pt).

6 Estimated resident population on 31-12-2018 (source: Regional Directorate of Statistics of Madeira, https://estatistica.madeira.gov.pt).
} 
Many entrepreneurs and recruiters pay attention to our project and have asked us for collaboration to publicize their job offers; many requests support for the preparation of their ads, with the aim of improving the ability to reach their recruitment needs, showing that we are also contributing to bring job demand and supply closer. The attention that the media has dedicated to the project, with the publication of some news and interviews, both in print and on radio and television, is also a proof of the importance of the project and how it can contribute to personal and regional development.

Moreover, the project has been distinguished in important, national and international events: Born from Knowledge Ideas ${ }^{7}$ 2016, Arrisca C ${ }^{8} 2016$ (Honorable mention in the Social Award), WSIS Prizes ${ }^{9}$ (nominated in several editions). In addition, it is included in the WSIS Stocktaking report, as a good practice and a valid proposal to be applied in other countries/regions. It should be noted that the WSIS Prizes and the WSIS Stocktaking are initiatives of the International Telecommunication Union (ITU), a United Nations agency specialized in the Information and Communication Technologies (ICT), aiming to distinguish and share best practices at a global level, and to recognize excellence in the implementation of local projects and actions, which can be replicated in other national or international contexts.

In a word, the project has proved to be a very important achievement, creating links between participants with regard to collaboration and common hope in the context of job opportunities, ultimately provoking changes towards a more inclusive and equitable society.

\section{CONCLUSION}

Technological evolution has brought about a networked society, mediated by technology, enhancing the individuals' ability to fulfill themselves as social beings. Digital social networks have offered us new horizons, in which we are no longer merely consumers of information, but knowledge producers, which implies the development of new skills.

On the other hand, education plays an important role in implementing strategies and methodologies, so that it can meet the new needs of individuals. Digital social networks offer new opportunities for individuals and groups in situations of unemployment, including in their sociability, as they contribute to overcome physical distances and produce new social interactions. But they can also be tools that promote active job search, contributing to the strengthening of employability.

In a glance at the project's implementation, we note that it has been developed with tools connected to globalization. Besides the internet, as a macro technology, we use Facebook (a paradigmatic example of digital online social networks), Blogger (a resource to create and maintain blogs) and many other technologies associated with ICT, in addition to the use of OER (an example of the production and use of educational content on a global scale).

In this context of globalization, the Project "REviver na Rede" emerged as a response to a local reality, because its main goal is to contribute to the resolution of a problem felt by a specific community. Moreover, its implementation highlighted the fact that Facebook can contribute to manage employability factors, like the isolation and social exclusion in unemployment. We conclude, therefore, that this digital online social network is a valid tool for the integration, socialization and active job search, helping to improve employability. Ultimately, Facebook can act as a local and community digital media, facilitating experiences impacting on its audiences, among which the unemployed members of the online "REviver na Rede" page and group.

Author contributions: All authors were involved in concept, design, collection of data, interpretation, writing, and critically revising the article. All authors approve the final version of the article.

Funding: The authors received no financial support for the research and/or authorship of this article.

Declaration of interest: Authors declare no competing interest.

\footnotetext{
${ }^{7}$ Born from Knowledge Ideas: competition promoted by the Ministry of Science, Technology and Higher Education, of the Portuguese Government.

8 "Arrisca C" is a competition promoted by the University of Coimbra (Portugal), aiming at stimulating the development of business concepts in which the creation of new companies is expected, including social entrepreneurship initiatives.

9 The WSIS Prizes is an international competition that aims to recognize projects with strategies oriented to local development that use the power of ICT as a development facilitator. It is promoted by the World Summit on the Information Society, an event that is promoted by the United Nations.
} 
Data availability: Data generated or analysed during this study are available from the authors on request.

\section{REFERENCES}

Alberto, M. (2005). A noção de empregabilidade: Origens e usos [The notion of employability: Origins and uses]. In Revista Trabalho \& Educação, n. 14. Retrieved May 09, 2021, from https://periodicos.ufmg.br/index.php/trabedu/article/view/8853

Arcoverde, A. (1998). Emprego/desemprego e redes de sociabilidade [Employment/unemployment and sociability networks]. Anais do XXI Seminário Latino-americano de Escolas de Trabalho Social. Retrieved September 11, 2020, from http://www.ts.ucr.ac.cr/binarios/congresos/reg/slets/slets-016-041.pdf

Bento, A. (2011). Desemprego, pobreza e exclusão social [Unemployment, poverty and social exclusion]. Imprensa da Universidade de Coimbra.

Boto, B. (2011). Relação entre adaptabilidade e empregabilidade [Relationship between adaptability and employability]. Universidade de Lisboa, Faculdade de Psicologia. Retrieved April 25, 2021, from http://repositorio.ul.pt/handle/10451/4963

Braudel, F. (1967). Civilisation matérielle et capitalisme. XV-XVII siècle [Material civilization and capitalism. XV-XVII century]. Armand Colin.

Castells, M. (2011). A sociedade em rede. A era da informação: Economia, sociedade e cultura [The network society. The information age: Economy, society and culture]. Fundação Calouste Gulbenkian.

Coutinho, V. (2014). The social book - tudo o que precisa de saber sobre o Facebook [The social book - everything you need to know about Facebook]. Conjuntura Atual.

Dias, P. (2014). Viver na sociedade digital - Tecnologias digitais, novas práticas e mudanças sociais [Living in the digital society - Digital technologies, new practices and social changes]. Principia.

Duarte, A. (1998). Vivências de desemprego e transformação dos modos de vida dos operários mineiros [Unemployment experiences and transformation of the miners' livelihoods]. Sociologia, 8, 247-317. Retrieved September 9, 2020, from http://ojs.letras.up.pt/index.php/Sociologia/article/view/2574

FCT - Fundação para a Ciência e a Tecnologia. (2015) Estratégia Nacional para a Inclusão e Literacia Digitais (2015-2020), Portugal [National Strategy for Digital Inclusion and Literacy (2015-2020), Portugal]. Retrieved September 25, 2020, from http://www.ticsociedade.pt/docs/ENILD.pdf

FCT - Fundação para a Ciência e a Tecnologia. (2017) INCoDe.2030 - Iniciativa Nacional Competências Digitais, Portugal [INCoDe.2030 - National Digital Skills Initiative, Portugal]. Retrieved September 25, 2020, from http://incode2030.gov.pt/sites/default/files/incode2030_pt_0.pdf

Furtado, J. (2007). Fractura digital e literacia: reequacionar as questões do acesso [Digital divide and literacy: rethinking access issues]. Comunicação \& Cultura, 3, 97-111. Retrieved September 2, 2020, from http://hdl.handle.net/10400.14/10381

Gispert, C. (1999). Enciclopédia de psicologia [Encyclopedia of psychology]. Oceano - Liarte.

Hoffman, R., \& Casnocha, B. (2014). Vencer nas redes sociais - Start up, um novo futuro [Winning on social media - Start up, a new future]. Clube do Autor.

Kelly Services (2011). Kelly Global Workforce Index [Report]. Afonso Carvalho.

Kirkpatrick, D. (2011). O Efeito Facebook - A história da empresa que está a mudar o mundo [The Facebook Effect - The story of the company that is changing the world]. Arcádia.

Latour, B. (2012). Reagregando o social: uma introdução à teoria do ator-rede [Reaggregating the social: An introduction to actor-network theory]. EDUFBA.

Lévy, P. (2003). A inteligência coletiva: por uma antropologia do ciberespaço [Collective intelligence: towards an anthropology of cyberspace] (4th ed.). São Loyola.

Loison, L. (2000). Mecanismos compensatórios do desemprego em Portugal: família e redes [Compensatory mechanisms for unemployment in Portugal: family and networks]. Atas do IV Congresso Português de Sociologia. Retrieved September 19, 2020, from https://aps.pt/wpcontent/uploads/2017/08/DPR462dd09ab4baf_1.pdf

Lopes, M., \& Cunha, M. (2011). O mundo é pequeno - O que podemos aprender sobre networking e as redes sociais [The world is small - What can we learn about networking and social media]. Actual Editora.

Marques, A. P. (2009). Trajectórias quebradas - A vivência do desemprego de longa duração [Broken trajectories - The experience of long-term unemployment]. Profedições. 
Martin, A. (2005) DigEuLit - a European framework for digital literacy: A progress report, (U. Glasgow, Ed.), International Journal of eliteracy. Retrieved April 25, 2021, from http://www.jelit.org/65/01/JeLit_Paper_31.pdf

Milgram, S. (1967). The small world problem. Psychology Today, 1(1), 61-67. Retrieved September 8, 2020, from http://snap.stanford.edu/class/cs224w-readings/milgram67smallworld.pdf

OECD (2005). Orientação escolar e profissional. Guia para decisores [Academic and professional guidance. Guide for decision makers]. Direcção Geral de Inovação e Desenvolvimento Curricular e Instituto de Orientação Profissional.

Oliveira, J. (2005). Tecnologia, trabalho e desemprego: Um desafio a empregabilidade [Technology, work and unemployment: A challenge to employability]. I/ Simpósio de Excelência em Gestão e Tecnologia - SEGeT. Retrieved September 7, 2020, from http://www.aedb.br/seget/arquivos/artigos05/377_ARTIGO\%20 ENVIADO\%20PARA\%200\%20CONGRESSO\%20DE\%20RESENDE-RJ.pdf

Paixão, M. P. (2021). Orientação e aconselhamento de carreira para jovens e jovens adultos: breve reflexão em torno dos principais desafios [Career guidance and counseling for young people and young adults: a brief reflection on the main challenges]. D \& F - Revista para Gestores e Formadores, $n^{\circ} 30$. Lisboa, Portugal: Instituto do Emprego e Formação Profissional. Retrieved April 25, 2021, from https://www.iefp.pt/publicacoes-iefp

Pinto, J. (2017). Formação aberta e online, redes sociais e inclusão digital: o projeto Reviver na Rede [Open and online training, social networks and digital inclusion: the Reviver na Rede project]. Universidade Aberta. http://hdl.handle.net/10400.2/6930

Pinto, J., Cardoso, T. \& Pestana. F. (2019). Competências digitais, qualificação e empregabilidade: Mapeamento dos documentos em Português com acesso aberto indexados no RCAAP em repositórios portugueses [Digital skills, qualification and employability: Mapping of documents in Portuguese with open access indexed in RCAAP in Portuguese repositories], In A. D. Figueiredo (Ed.), RE@D - Revista de Educação a Distância e Elearning - Competências Digitais (n. 2, v. 1, pp. 26-40). Universidade Aberta. Retrieved April 25, 2021, from https://repositorioaberto.uab.pt/handle/10400.2/8264

Recuero, R. (2009). Redes sociais na Internet [social networks on the internet]. Sulina. https://doi.org/10.30962/ec.v2i0.28

Rheingold, H. (2012). Net smart - How to thrive online. MIT Press.

Santarosa, L., Debora, C., \& Schneider, F. (2014). Tecnologias na Web 2.0: o empoderamento na educação aberta [Technologies in Web 2.0: empowerment in open education]. Colóquio Luso-Brasileiro de Educação a Distância e Elearning. Retrieved August 13, 2020, from http://repositorioaberto.uab.pt/handle/10400.2/3071

Santos, A. (2010). Desemprego e trajectos de exclusão social [Unemployment and social exclusion pathways]. Universidade Nova de Lisboa.

Tavares, S. R. (2013). Plataforma para gestão de conteúdos de entretenimento [Entertainment content management platform]. Universidade do Porto.

Turkle, S. (1997). A vida no ecrã [life on screen]. Relógio d'Água.

Vermelho, S., Velho, A., Bonkovoski, A., \& Pirola, A. (2014). Refletindo sobre as redes sociais digitais [Reflecting on digital social networks]. Educação \& Sociedade, 35(126), 179-196. Retrieved September 4, 2020, from https://doi.org/10.1590/S0101-73302014000100011

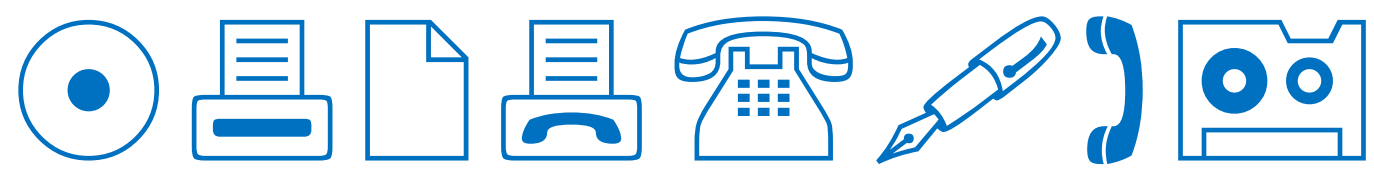

